\title{
De professionellas syn på patienters kontakter med anhöriga
}

Västra Mark 1931-1981

KRISTINA ENGWALL

\begin{abstract}
I journalerna för patienterna som var intagna på sinnessjukhuset Västra Mark finns brevväxlingen mellan de anhöriga och överläkaren bevarad. Av dessa brev framgår tydligt den förändring som skedde under 1960talet då anhöriga övergick från att ses som obetydliga till att betraktas som viktiga i patientens liv.
\end{abstract}

Hon har ingen kontakt med världen omkring sig och bryr sig ej om någon. Jag tror därför knappast, att ett besök av Eder skulle vara till någon glädje vare sig för Eder eller Eder dotter. ${ }^{1}$

Detta svar gav överläkaren på Västra Marks sjukhus till en mor vars dotter var patient på sjukhuset. Året var 1947 och modern hade frågat om hennes dotter skulle bli glad över ett besök. Patienten hade tagits in på Västra Mark år 1941 då hon var 27 år gammal. Tidigare hade hon vistats på andra sinnesslöanstalter, men hon ansågs vara för störande och våldsam för att kunna vara kvar där. Is-

Fil. mag Kristina Engwall (född 1969) är doktorand i historia på Örebro universitet. Hon arbetar med en avhandling om sinnessjukhuset Västra Mark. tället skickades hon till Västra Mark, som var ett sjukhus för s.k. asociala och imbecilla kvinnor. Där kom hon att stanna i trettio år innan hon överflyttades till ett vårdhem $\mathrm{i}$ hemlänet. Under dessa trettio år höll modern kontakt med dottern och besökte henne vartannat år, trots överläkarens skepsis.

Alla patienter på Västra Mark fick dock inte besök av släktingar. Det finns exempel på patienter som inte fått besök på trettio till fyrtio år. Vad berodde detta på? För att skapa och upprätthålla en relation mellan patienter och anhöriga på Västra Mark var åtminstone tre olika aktörer involverade,

1 Landsarkivet i Uppsala (ULA) Västra Mark Journal nr 26/41 Fla:39. Fortsättningsvis anges enbart journalnummer. 
nämligen patienterna själva, deras anhöriga och de professionella dvs. läkare, byråkrater och övrig vårdpersonal. ${ }^{2}$ De professionellas syn på vilken omfattning relationer mellan patienter och deras anhöriga skulle ha, utgjorde till stor del ramarna för hur patienternas relationer såg ut. Därmed blir det intressant att se vilken syn de professionella hade på relationerna mellan patienter och anhöriga.

Inom historisk forskning saknas idag kunskaper inom detta område. Den forskning som finns om människor med utvecklingsstörning och deras relationer till anhöriga berör främst nutida förhållanden. Pedagogen Britta Högberg (1996:100-101) redogör t.ex. i sin avhandling för barnhabiliteringens utveckling i fråga om föräldrarollen. I den relation som finns mellan personal, föräldrar och system hade föräldrarna först rollen som patienter, senare som coterapeuter och idag som partners till personalen. Pedagogen Anders Gustavssons forskning (1992:222) berör människor som uppfattas som avvikande och deras sociala kontaktnät. Han visar att dessa människors viktigaste relationer är just inom familjen. Familjen är det sociala sammanhang där de avvikande människorna inte väljs bort.

Om relationerna mellan professionella, anhöriga och patienter i ett tidigare historiskt skede finns en allmänkunskap som ofta

2 De professionella betecknar i detta sammanhang de som genom sitt arbete eller förtroendeuppdrag kom i kontakt med patienterna. Förhållandena mellan de professionella och patienterna reglerades främst av lagar och förordningar. Det behövde därmed inte finnas någon personlig kontakt mellan professionella och patienter. bygger på de inblandades egna erfarenheter och minnen. Jag avser i denna artikel att visa på relationerna mellan patienterna på en anstalt, deras anhöriga samt personal utifrån ett skriftligt journalmaterial som skrivits för sin samtid. Syftet är i huvudsak att i ett historiskt material kunna belägga hur relationerna faktiskt såg ut och förändrades över tid. Deskriptionen spelar därmed en viktig roll $i$ artikeln. Artikeln inleds med en kartläggning av patienternas anhöriga, dvs. deras föräldrar och egna familjer. Därefter belyses de professionellas syn på anhörigkontakter. Slutligen vill jag ställa frågan vilken betydelse kontakten eller icke-kontakten mellan anhöriga och patienter kan ha haft för patienternas ställning i samhället.

Västra Mark var ett statligt sinnessjukhus, men tog emot kvinnor som betecknades som "asociala" och "imbecillaw. Asocialiteten tycks i de flesta fall ha utgjorts av vad samtiden kallade »sexuell opålitlighet« eller våldsamhet. "Imbecillı var det ord som användes för vad som idag kan sägas motsvara lindrigt utvecklingsstörd. ${ }^{3}$ Vissa patienter kom till Västra Mark på grund av straffriförklaring. Västra Mark var det enda sinnessjukhuset i Sverige för masociala och imbecilla« kvinnor. Därutöver fanns det två sinnessjukhus för »asociala och imbecilla« män.

3 Begrepp såsom sinnesslö, imbecill, idiot osv. är svåra att ge en tydlig definition, eftersom de inte syftar på samma kategori som idag kallas utvecklingsstörda. Gruppen sinnesslöa var en större grupp än det vi idag kallar utvecklingsstörda. I vissa sammanhang tycks t.ex. moraliska hänsyn fått ligga till grund för beteckningen sinnesslö. (Runcis, 1998b) I artikeln använder jag beteckningen sinnesslö fram till 1967 och därefter beteckningen utvecklingsstörd. 
Dessa sinnessjukhus tillkom i den tid då sinnesslöa människor sågs som en fara för samhället och man ansåg att samhället måste skyddas från dem (Söder, 1984:85-93). Upprättandet av dessa sinnessjukhus var med det synsättet en metod för samhället att skydda sig från de sinnesslöa. Steriliseringslagarna som stiftades några år senare var en annan metod. År 1967 omvandlades Västra Mark till ett specialsjukhus som stod öppet även för män. Därmed övertogs ansvaret från staten av landstinget.

\section{Källmaterial}

Artikeln bygger främst på journaler från Västra Marks Sjukhus under perioden 1931-1981. Urvalet av journaler utgörs av samtliga nyintagna vart femte år. Sammanlagt grundar sig artikeln på 518 journaler. ${ }^{4}$ I journalerna finns levnadsberättelse, uppgifter om anhöriga, läkarintyg, eventuell brevväxling angående patienten och dagsanteckningar om patienten.

Journaler är ett speciellt källmaterial på så sätt att de är skrivna ur läkarens perspektiv. Etnologen Lars-Eric Jönsson (1998:52) påpekar i sin avhandling att journalen är ett resultat av mötet mellan patienten, psykiatern och anstalten som ger en speciell kunskap om patienten. Läkarens syn på patienten dominerar journalen. Trots detta kan även patientens vilja och åsikter framskymta, t.ex. i brev och brevsvar eller när patienten motsätter sig något. Journalerna erbjuder därmed, trots vinklingen, en möjlighet att se individen bakom patienten. Ett välkänt problem inom medicinhistoria är just svårigheterna att få tag på patienternas syn

4 Av dessa journaler handlar bara tre om män. på sin situation. Detta försummade forskningsområde gör att nya kreativa metoder måste användas för att nå patienternas upplevelse (Johannisson, 1988:20-23). Användandet av journaler som källmaterial kräver en medvetenhet om den funktion journaler haft och även en lyhördhet för att upptäcka patientens röst.

Ett annat källmaterial som kompletterar journalmaterialet är patienters och anhörigas skrivelser till Medicinalstyrelsen/Socialstyrelsen. Dessa skrivelser är av skiftande kvalitet men visar ändå på en aktiv handling i syfte att förändra. ${ }^{5}$

Trots att journalerna valts ut enligt principen nya intagna var femte år kan inga markanta förändringar avläsas över tid, i synnerhet inte före 1960-talet. På Västra Mark kom många av de 350 patienter som togs in år 1931 att stanna länge. Detta medförde att antalet patienter som kunde tas in senare var relativt få, ca 40 per år. De förändringar som skett inom sinnesslövården i fråga om nya kategoriseringar kan därmed inte avläsas i källmaterialet från Västra Mark. Utvecklingen var tämligen statisk på Västra Mark. Även det faktum att flera lagar angående sinnesslövården inte berörde Västra Mark bidrog till frånvaron av förändringar.

\section{Barndomsförhållanden}

Varje journal inleds med en kort beskrivning av patienternas barndom och familjeförhållanden. Patienternas familjebakgrund

5 Jfr med Lena Steinholtz Ekecrantz avhandling Patienternas psykiatri. En studie av institutionella erfarenheter som till stor del bygger på patientskrivelser. 
visar att de allra flesta med enbart enstaka undantag kommer ifrån arbetarklassen. Av levnadsberättelserna framgår att 45 procent vuxit upp på anstalt eller i fosterhem. ${ }^{6}$ De har före sexton års ålder placerats i fosterhem, på barnhem eller på sinnesslöanstalter. Flera av kvinnorna har dessutom flyttats mellan flera olika anstalter eller fosterhem.

Anledningarna till att de omhändertagits som barn har varit flera. Vissa journaler anger att patienterna var födda "utom äktenskapet", vilket var stigmatiserande för såväl moder som barn. Det gällde i synnerhet för de patienter som föddes i slutet av 1800-talet och i början av 1900-talet. Dessa barns chanser till överlevnad och välbefinnande var sämre än för barn födda inom äktenskapet, vilket inte minst den höga dödligheten för oäkta barn visar (Bengtsson,1996). Patienter som var barn före år 1918 kunde ha upplevt utauktionering, dvs. de omhändertogs av det hushåll som krävde minst ersättning. En del av patienterna hade omhändertagits på barnavårdsnämndens initiativ eftersom man ansåg att de vanvårdades i sina hem eller att det förelåg en risk för att barnen skulle bli "vanartiga .

I vissa fall är det dock uppenbart att det var klassificeringen som sinnesslö som orsakade en anstaltsplacering. En del av dessa sinnesslöa barn bodde i familjer som bedömdes som bra, men de placerades ändå på sinnesslöanstalter. I början av seklet inrättades en rad anstalter och en klassificeringsiver tog vid; bildbara sinnesslöa fick inte vara med obildbara sinnesslöa, "välarta-

647 procent har växt upp i sina föräldrahem och för 8 procent framgår inte var kvinnorna växt upp. de" barn fick inte vara med "vanartiga", epileptiker fick egna anstalter liksom vanföra, blinda och döva (Söder, 1984). En speciell anstalt öppnades även för vanartiga sinnesslöa flickor år 1924 i Vänersborg. Därifrån kom sammanlagt 43 patienter direkt till Västra Mark.

Under 1800-talet och fram till början av 1900-talet försörjdes de »behövande» i fattighuset, på fattiggården, genom rotegång eller utauktionering. Detta system medförde trots andra brister ändå kontakter med familjer och lokalsamhälle, vilket inte fanns i lika stor utsträckning inom anstaltsväsendet.

Flera anstalter arbetade med s.k. kontrollerad familjevård, dvs. sinnesslöa placerades ut i familjer mot betalning. Fro.m. år 1914 beviljades familjevården statliga bidrag. En starkt bidragande orsak var att vårdformen var billigare än anstaltsvård (Söder 1984:133-135). På Västra Mark var dock familjevården mycket begränsad. År 1948 hade fortfarande inte familjevård anordnats vid Västra Mark och det var då det sista sjukhuset i sitt slag som inte ordnat detta. Man försökte lösa problemet genom att anställa en hjälpverksamhetsföreståndarinna, men försöken med kontrollerad familjevård misslyckades. ${ }^{7}$ År 1950 redovisades att tre hem användes för familjevård varav ett hem tagits bort då det visat sig olämpligt. Överläkaren menade dessutom att antalet patienter som skulle kunna tänkas komma i

7 ULA Sjukhusintendenten Skrivelser från Medicinalstyrelsen och andra centrala myndigheter 1930-1959 E 1:a skrivelser den 8 april 1948 samt den 2 april 1948 
fråga för kontrollerad familjevård omfattande enbart ett par enstaka fall. ${ }^{8}$

Av de kvinnor på Västra Mark som föddes på slutet av 1800-talet och fram till 1930-talet hade samtliga någon slags erfarenhet av att bo i familj. Av dem som är födda senare finns det ett fåtal som aldrig bott $i$ familj utan enbart på anstalter. De har tidigt kommit till barnhem eller spädbarnshem för att sedan förflyttas vidare till vårdhem eller skolhem..$^{9}$ En patient hade vid 23 års ålder redan hunnit vara på elva olika institutioner. ${ }^{10}$ En annan patient hade hunnit med tretton förflyttningar under sex år. ${ }^{11}$ Överläkaren reagerade på 1970-talet mycket starkt i båda dessa fall. I det ena fallet inkrävde han en komplett redogörelse från omsorgsstyrelsen över anstalter och fosterhem där patienten varit, eftersom han var »...benägen att tro att detta myckna flyttande ingal unda är en likgiltig sak....... ${ }^{12}$ I det andra fallet skrev han i journalen "...att yngre patienter vårdas allt kortare tid på allt fler anstalter, antagligen till mycket stor skada på deras psykiska tillstånd. .1 ${ }^{13}$

De kvinnor som flyttats runt mellan flera olika hem och anstalter riskerade att förlora kontakten med sina biologiska föräldrar, liksom föräldrarna kunde förlora kontakten med sina barn. Besluten om barnens placering och framtid förlades i flera fall till barnavårdsnämnden eller fattigvården. För de sinnesslöa barnens placeringar spelade lä-

8 ULA Årsredogörelse 1950 Sjukhuschefen BII:2

9 Se t.ex. 24/56 Fla:88; 41/56 Fla:93; 7/66

FIa:87 samt 8/76 Fla:123

10 12/71 FIa:113

11 27/71 FIa:116

12 27/71 FIa:116

13 12/71 FIa:113 karna och deras bedömingar en viktig roll. Ansvaret för dessa barn lades på professionella yrkesgrupper istället för på föräldrarna.

\section{Patienternas familjebildning}

Enligt lag från år 1915 var sinnesslöa förhindrade att gifta sig. "Ej må den träda i äktenskap, som är sinnessjuk eller sinnesslö. ${ }^{14}$ De sinnesslöa noterades i kyrkobokföringen och fick därmed pga. medicinskt äktenskapshinder inte tillåtelse att gifta sig. Syftet med lagen var att hindra sinnesslöa från att sätta barn till världen. Det medicinska äktenskapshindret fanns kvar till 1973. År 1945 ändrades dock lagen och sinnesslöa fick möjlighet att begära dispens för att gifta sig. Dispens utdelades ibland under förutsättning att den som var antecknad som sinnesslö underkastade sig sterilisering.

Att äktenskapshindret inte alltid fungerade såsom lagstiftarna hade tänkt sig visar ett fall på 1920-talet då en kvinna sammanlevde med en man som periodvis varit på sinnessjukhus. Tillsammans hade de två barn. Pga. mannens sinnessjukdom fick de inte gifta sig. Situationen bedömdes i journalen som mycket olämplig, speciellt ur rashygienisk synpunkt.

Då den hon hushållar för, som äfven är fader till hennes båda barn sjelf varit sinnessjuk, och synes vara mycket fästad vid henne, är fortsatt samlif säkerligen ödesdigert från rashygienisk synpunkt. ${ }^{15}$

Kvinnan fick senare även hon psykiska pro-

14 SFS 1915:426 2 kap 5§

15 4/31 Fla:9

Kristina Engwall: De profesionellas syn på patienters... 
blem och vid undersökning ansågs hemmet och barnen vara vanvårdade. År 1931 togs hon in på Västra Mark.

Patienterna på Västra Mark borde utifrån dessa förutsättningar vara ogifta, vilket de flesta var, men 5 procent var gifta och 4,5 procent var frånskilda eller änkor.

Civilstånd för patienterna på Västra Mark 1931-1981

$\begin{array}{lrrrr}\text { ogifta } & \text { gifta } & \text { skilda } & \text { änkor } & \text { okänt } \\ 89 \% & 5 \% & 3 \% & 1,5 \% & 1,5 \% \\ (580) & (32) & (19) & (10) & (9)\end{array}$

Källa:ULA Patientregister D I: I -6Västra Marks sjukhus

Det är dock intressant att se närmare på vilka kvinnor som var gifta, frånskilda eller änkor. Istället för att se patienterna som en enda grupp kan vi indela dem i straffriförklarade och icke-straffriförklarade. Av de patienter som ingår $i$ undersökningen var 105 stycken straffriförklarade. Av dessa var 28 stycken, eller 27 procent gifta, frånskilda eller änkor. Av de övriga patienterna hade bara 6 procent någon gång varit gifta. Det var således vanligare att de straffriförklarade hade varit gifta eller var gifta än de övriga patienterna.

De straffriförklarade kvinnornas masocialitet" och "imbecillitet" hade uppdagats i samband med ett brott. Fram till brottet hade de sålunda fungerat någorlunda i samhället och de hade t.ex. fått gifta sig, eftersom de inte var registrerade som sinnesslöa i kyrkböckerna. Straffriförklarade som var ogifta då de kom till Västra Mark kunde dock drabbas av det medicinska äktenskaps- förbudet efter sin vistelse där, eftersom patienterna på Västra Mark anmäldes som sinneslöa till pastorsämbetet. Den anteckningen resulterade i att de inte kunde gifta sig. En patient som tidigare varit gift under sju år skilde sig år 1944. Efter detta hamnade hon på Västra Mark och därmed kunde hon efter utskrivningen inte gifta sig utan tillstånd från Medicinalstyrelsen. ${ }^{16}$

Ibland återkom kvinnorna till överläkaren på Västra Mark några år efter utskrivningen för att få hjälp med att häva äktenskapshindret. I ett fall runt 1950 svarade läkaren på Västra Mark: „För egen del har jag i princip intet emot att /namn/ gifter sig om mannen är en vederhäftig och pålitlig person som ej är psykiskt undermålig eller abnorm eller ' lika omdömeslös som /namn/. ${ }^{117}$ Då kvinnorna återkom till överläkaren på Västra Mark efter det att de skrivits ut tycks det som läkaren gjort en individuell bedömning där äktenskapshindret ibland hävts, men inte alltid.

I slutet av 1960-talet och under 1970-talet blev samboende utan äktenskap allt vanligare i samhället. Detta avspeglade sig även på Västra Mark där en del patienter skrevs ut till sina fästmän och ett samboende utan att de var gifta. Västra Mark var en enkönad miljö fram till 1967 och där var det svårt att träffa män. Ibland ordnas visserligen danser tillsammans med t.ex. Salberga som hade manliga patienter, men de flesta pojkvännerna var bekantskaper sedan tidigare eller män som patienterna träffat under rymningar eller försöksutskrivningar.

16 10/51 Fla:43

17 39/46 Flb:21 


\section{Traditionell kvinnosyn}

Kvinnorna på Västra Mark skolades in i ett mycket traditionellt könsmönster med ansvar för hem, mat och tvätt. Det var en arbetsfördelning som inte ifrågasattes förrän på 1960-talet i samhället. Idén om ett gemensamt ansvar för hem och barn är en relativt sen 1900-talsföreteelse. Det är därmed inte förvånande att man från sjukhusets sida uppmuntrade patienterna till traditionellt kvinnoarbete, som framgår av följande brevsvar från läkaren år 1969:

Vi förstår att hon hos Eder sköter hushållet, lagar mat, sköter kläder, etc. Vi är angelägna om att hon skall göra det på ett sätt som kan vara till Eder fulla belåtenhet. Vi tänker nu under hösten, ungefär från början av oktober, starta en kurs för den bättre delen av våra patienter. På denna kurs skall de lära sig sådant som behövs, som behövs (sic) om man skall sköta hushåll för en karl. Kursen skall omfatta matlagning med särskild tonvikt på sådan mat som en karl tycker om. Kursdeltagarna skall även lära sig sköta kläder, också manskläder. ${ }^{18}$

En traditionell kvinnoroll var även vad många av patienterna eftersträvade. Att bilda familj och sköta hushåll och barn var för dem ett tydligt tecken på normalitet. Mycket stolta skickade vissa av de utskrivna patienterna bröllopskort till Västra Mark och journalerna avslutades med positiva besked om att det fungerade väl med de nya familjerna. ${ }^{19}$

18 30/36 Fla:48

19 T.ex. 21/61 Fla:64, 29/61 Fla:109, 3/71 Fla:118

\section{Patienternas barn}

Trots samhällets strävan att förhindra sinnesslöa från att föda barn genom äktenskapsförbud, anstaltsvistelser och steriliseringar hade flera av kvinnorna på Västra Mark barn. Då steriliseringslagen diskuterades år 1934 räknade överläkaren på Västra Mark hur många av patienterna som hade barn. "... av de 343 patienterna hava 116 fått barn, sammanlagt 247 st., varav 194 äro födda utom äktenskap. . $^{20}$

Det hände att kvinnorna var gravida då de kom till Västra Mark eller att de blev gravida under försöksutskrivning. I dessa fall avbröts graviditeten genom abort och ibland steriliserades kvinnorna samtidigt. Patienterna bedömdes som olämpliga mödrar vilket framgår av de orsaker som angavs till deras sterilisering. Den "sociala indikationen" i steriliseringssammanhang betydde att man ansågs olämplig som förälder. I de fall graviditeten var för långt gången för abort omhändertogs barnet genast och fördes till spädbarnshem eller barnhem. ${ }^{21}$

I början av Västra Marks historia finns inga uppgifter om att kvinnorna höll kontakt med sina barn. På slutet av 1960-talet finns anteckningar om en patient som sporadiskt hälsade på sitt barn på barnhemmet. Hennes föräldrar tog senare barnet som fosterbarn, innan hon senare själv övertog vårdnaden om barnet. ${ }^{22}$ På 1970-talet förändrades synen på patienternas kontakt med sina

20 RA Medicinalstyrelsen Sinnessjukvårdsbyrån Överinspektörens berättelser Inspektion År 1934 (EIIc: 11)

21 Se t.ex. 11/46 Flb:20 och 40/61 Fla:103

22 10/66 Fla:115

Kristina Engwall: De profesionellas syn på patienters... 
barn och man sökte från personalens sida upp barn till patienterna. ${ }^{23}$

\section{De professionellas syn på anhöriga}

Patienternas på Västra Mark anhörigkontakter utgjordes således dels av deras föräldrar och syskon, dels egna familjer och ibland även barn. För knappt hälften av patienterna hade dock barndomen inneburit flera uppbrott. De hade varit i ett eller flera fosterhem, på en eller flera anstalter. Intagningen på Västra Mark var ytterligare ett uppbrott som påverkade relationen till de anhöriga. Hur såg då de professionella på relationerna mellan patienterna på Västra Mark och anhöriga? Synen på relationerna ändrades efter hand och kan indelas i två skeden. Det första skedet sträcker sig från 1931 fram till 1960-talet och det andra skedet från 1960-talet till 1981 då Västra Mark lades ner.

Gränsdragningen mellan de olika skedena på 1960-talet kan tyckas sen jämfört med den allmänna utvecklingen inom omsorgen. Många av de förändringar som berörde människor med utvecklingsstörning påverkade dock inte verksamheten på Västra Mark. Den första lagen som riktade sig till sinnesslöa kom 1944, men den omfattade enbart bildbara sinnesslöa barn, inte vuxna. ${ }^{24}$ År 1954 kom nästa lag och inte heller den fick betydelse på Västra Mark. ${ }^{25}$ Den lag som fick betydelse för Västra Mark

23 Se t.ex. 62/31 Fla:11

24 Lag om undervisning och vård av bildbara sinnesslöa SFS 1944:477

25 Lag om undervisning och vård av vissa psykiskt efterblivna SFS 1954:483 var Lag angående omsorger om vissa psykiskt utvecklingsstörda som kom år 1967. ${ }^{26}$ Det var den lag som omvandlade Västra Mark till ett specialsjukhus och landstinget övertog därmed ansvaret. Förändringar i verksamheten på Västra Mark försvårades av de olämpliga lokalerna. Sjukhuset var inrymt i ett gammalt regemente. Trots ombyggnationer på 1960-talet saknades förutsättningar för en modern omsorg. Dessutom hade man svårigheter att rekrytera kompetent personal. Under 1960-talet påpekades dessa brister i flera av inspektionsberättelserna. ${ }^{27}$

\section{Första skedet: de anhörigas obetydliga roll}

Majoriteten av kvinnorna som togs in på Västra Mark kom direkt från någon annan anstalt. Kvinnorna var redan i de professionellas vård och de anhöriga hade oftast accepterat de professionellas kunskapsmonopol på vad som ansågs bäst för patienten. Det hände att kvinnorna förflyttades från en anstalt till en annan utan att familjen informerades, vilket brev från anhöriga till överläkaren visar:

»Jag blef så ledsen när jag kom till Lund och hon inte fans där, inte någon släktingar underrättade. $\|^{28}$

„Har fått ett mer än vanligt virrigt brev från min syster, /namn/, och att hon är på ett sjukhus, är ju alldeles förbluffande för mig, då jag inte förrut hört något om att hon är flyttad dit..129

26 SFS 1967:940

27 Socialstyrelsen, mentalsjukvårdsbyrån, inspektionsberättelse 1963 EII f:5 samt inspektionsberättelse 1965 EII f:7

28 246/31Fla: 1 odaterat brev, troligen från 1932 29 32/51 Fla:29 brev från 1952 
Överhuvudtaget tycks kontakten med anhöriga oftast ha skett via brev. Patienterna har skrivit brev själva eller fått hjälp att skriva brev av sköterskorna. Av ett brev från en patient till sina föräldrar framgår att patienterna på Västra Mark fick skriva hem var fjortonde dag. „Kära mamma! Jag skall nu skriva till dig som jag lovade dig innan jag for. Vi får ej skriva mer än ett brev var 14 dag. Jag mår bra hoppas ni gör detsamma....1 ${ }^{30}$

De anhöriga har skrivit till patienterna, men även till överläkaren för att få besked om döttrars, mödrars eller systrars tillstånd. Det finns även exempel på anhöriga som fått hjälp att skriva brev av kyrkoherden eller fattigvårdsordföranden. ${ }^{31}$ Flera av breven från de anhöriga innehåller direkta frågor om patienterna har tillåtelse till att skriva brev. ${ }^{32}$ Överläkaren svarade i dessa fall att patienterna fick skriva brev men han ifrågasatte ibland om patienterna skulle göra det eller om breven skulle vara till någons glädje. År 1941 svarade överläkaren en syster att „Det möter intet hinder att skriva brev till henne. Dock torde hon ej ha så stor glädje av att få brev.⿲133 Angående en annan patient svarade överläkaren år 1931 «att skriva brev står henne fritt men hon kommer sig ej för därmed. ${ }^{34}$

Kontakten med föräldrar, syskon och makar försvårades dessutom av att Västra Mark var ett statligt sinnessjukhus med pa-

30 RA Akter Sinnessjuknämnden E1:50 (1941) diarie 1808/41

31 14/41 Fla:5l och 233/31 Fla:2

32 Se t.ex. 246/31 Fla: 1

33 235/31 Fla:2

34 246/31 Fla:1 tienter från hela landet och avstånden blev därför ofta långa. "Det är så långt att resa så jag kan aldrig mer få se henne» skrev en syster. $^{35}$ En far skrev år 1946 att »...som Ni säkerligen förstår är jag och min hustru varmt fästade vid henne och vi skulle gärna se om hon hade kunnat komma söder över. Som det nu är kan vi icke träffa henne någon gång. ${ }^{36}$

De långa avstånden kunde även medföra problem då patienter skulle hälsa på anhöriga. Vissa patienter klarade inte att resa själva utan måste bli hämtade. År 1953 skrev en fosterbror och undrade om han kunde hämta patienten under mars månad eftersom vårbruket sedan tog vid och han hade svårare att komma till Örebro. ${ }^{37}$ I detta fall fick dock patienten inte lov att åka då hon enligt läkaren blivit sämre och »Ni skulle ej ha möjlighet att bereda /namn/ den vård och tillsyn varav hon är i behov, och hon bleve Eder snart till stort bekymmer. ${ }^{38}$

Flera av de anhöriga som vände sig till överläkaren undrade om de fick ta hem sina döttrar, mödrar eller systrar. Vid nekande svar kunde läkaren hänvisa till att de anhöriga inte klarade av att ge rätt vård och ibland anfördes argumentet att det skulle bli svårt att få patienten att återvända till Västra Mark. I samband med en förfrågan på 1940talet om modern fick ta hem dottern över jul fick hon svaret av läkaren

...att jag kan ej medgiva att hon får lämna sjukhuset för ett besök i hemmet över julen. Dessa julresor äro nämligen förenade med stora olä-

35 246/31 Fla: 1

36 7/46 Flb:26

37 12/51Fla:78

38 12/51 Fla:78

Kristina Engwall: De profesionellas syn på patienters... 
genheter för sjukhuset. De medföra bl. a att pat. som ej kunna få resa bli misslynta och oroliga och så blir det ofta tråkigheter när en permitterad pat. skall återvända till sjukhuset. ${ }^{39}$

\section{Behovet av stöd för anhöriga}

Flera av patienterna på Västra Mark var vad vi idag skulle kalla mycket vårdkrävande. För de anhöriga som fick hem patienterna på besök var det därför inte helt enkelt, då det behövdes mycket tillsyn. Det ställdes stora krav på de anhöriga och stödet på hemorten var otillräckligt eller obefintligt. Det saknades möjligheter till någon form av avlastning. En patient utskrevs till exempel år 1952 till sina vuxna dotter som hade tre småbarn. Det var naturligtvis en arbetsam situation med både tre barn och en mor som krävde mycket tillsyn. Efter en tid ville hon ha avlastning. Någon sådan hjälp kunde inte Västra Mark bistå med utan hon råddes till att kontakta socialen. ${ }^{40}$

\section{De motsträviga anhöriga}

Brevväxling som finns mellan anhöriga och överläkaren visar på en stor respekt för överläkarens professionalitet och hans åsikter om vad som var bäst för patienten. Flera anhöriga frågade t.o.m. om de fick skriva till patienten och om patienten får skriva till dem. Att överläkaren visste bäst var något som sällan ifrågasattes. Det var också hos överläkaren som makten låg att ta in patienter och skriva ut patienter. ${ }^{41}$ Några få

39 5/4l Fla:30 pat. är förkortning av patient

40 35/51 Fla:9

41 Undantagna var de straffriförklarade där rätten till in- och utskrivning låg hos sinnessjuknämnden. anhöriga har dock ifrågasatt vistelsen på Västra Mark och vänt sig till andra myndigheter för att patienten ska skrivas ut .

I ett av de fall där fadern försökt få ut sin dotter från Västra Mark hade dottern varit omhändertagen sedan tre års ålder. Barnavårdsnämnden hade tvångsomhändertagit dottern då den ansåg att hon vanvårdades. Av journalen på Västra Mark framgår att fadern en period hade vistats på sinnessjukhus och skrivits ut som sinnesslö och moderns sinnestillstånd beskrevs som "suspekt». Enligt barnavårdsnämnden insåg inte föräldrarna att flickan var psykiskt sjuk. Vid ett flertal gånger hade fadern på eget initiativ hämtat flickan från de anstalter hon varit på och barnavårdsnämnden hade tvingats begära polishandräckning för att ta tillbaka flickan. I den vårdattest som följde patienten till Västra Mark står följande:

Kan vara häftig och retsam men i allmänhet oförarglig och rätt lättskött. Däremot bereder föräldrarna mycket stort besvär. Anser flickan fullt normal och vill ha hem henne, skriver och ringer, varvid de uppträder mycket pockande och obalanserat. ${ }^{42}$

När dottern var på Västra Mark i början av 1950-talet skrev fadern flera brev för att få hem flickan där han använde sig av hänvisningar till lagen och högre myndighetspersoner. Till slut tog han hjälp av en jurist för att få dottern utskriven.

Samtidigt med arbetet att få sin dotter utskriven drev fadern en kampanj för att han skulle få gifta sig med dotterns mor. Föräldrarna fick inte gifta sig, troligtvis för att mannen ansågs vara sinnesslö. Efter under-

42 29/51 Fla:87 
sökningar och skrivelser hävdes äktenskapsförbudet och de kunde gifta sig. Efter äktenskapet vände sig mannen åter till Västra Mark och bad om att få hem dottern. En läkare, som varit med i utredningen om mannen, ansåg att de kunde få ta hem dottern, men tillade: "Skulle försöket misslyckas är ingen större skada skedd och lämpliga motåtgärder får väl då i sinom tid vidtagas«. ${ }^{43}$

Det finns ytterligare ett fall i slutet av 1940-talet där något av en kamp utspelat sig för att dottern skulle skrivas ut. Dottern hade växt upp i föräldrahemmet med elva syskon. Hon hade en gång blivit dömd för stöld. 17 år gammal födde hon ett barn och kom till ett mödrahem. Där skötte hon sig enligt journalen så illa att hon blev hemskickad. Därefter vidtog flera olika anstaltsbesök innan hon slutligen kom till Västra Mark. Fadern begärde flera gånger permission för sin dotter vilket inte beviljades. Anledningen var att överläkaren ansåg patienten vara «opålitlig« såväl «sexuellt« som «i övrigt" och att det skulle bli problem att återföra henne till Västra Mark. T.om. några av kommuninvånarna engagerade sig $\mathrm{i}$ fallet och skrev ett intyg där de försäkrade att flickan skulle bli väl omhändertagen av familjen. Intygsundertecknarna menade att anledningen till hennes anstaltskarriär var att de styrande politikerna i kommunen ogillade familjen. Efter sterilisering försöksutskrevs dottern till sina föräldrar. ${ }^{44}$

Ovanstående två fall är exceptionella. Det hörde till ovanligheterna att anhöriga så ihärdigt motsatte sig de professionellas beslut. Det är också tydligt att dessa båda män

43 29/51 Fla:87

44 13/46 Flb:26 inte hörde till de välrenommerade i samhället. Den ena mannen betraktades som sinnessjuk och sinnesslö. Den andra mannen var hemmansägare med tolv barn, där samtliga barn betraktades som mindre begåvade. De båda männen värjde sig mot beskrivningarna av deras hem som olämpliga. Männen ansågs vara besvärliga av de professionella, men i dessa fall slutade det hela med att döttrarna skrevs ut från Västra Mark.

\section{Relationerna under första skedet}

Hur kan man då beskriva de professionellas syn på relationen mellan anhöriga och patienterna på Västra Mark under den första perioden? I synnerhet överläkarens svar till anhöriga om eventuell kontakt med patienterna vittnar om att relationen mellan anhöriga och patienter på Västra Mark inte betraktades som viktig att upprätthålla. Kunskaperna om bästa vård ansågs finnas hos de professionella. Beslut om patienterna fattades av överläkaren ensam, utan samråd med vare sig patienter eller anhöriga. De professionellas syn på patienten illustreras av att breven om utskrivning alltid ställdes till förmyndaren, aldrig till patienten själv.

I ett fåtal fall diskuterade dock de professionella kontakten mellan anhöriga och patienterna. De gällde främst de fall där de professionella ansåg att kontakt defintivt inte var lämplig. I ett fall avrådde överläkaren en far som utsatt sin dotter för sexuella övergrepp från fler besök på Västra Mark. Besöket av fadern hade gjort kvinnan mycket upprörd och överläkaren menade att han istället kunde meddela per brev till fadern hur dottern mådde. ${ }^{45}$ I övrigt handlade det

45 21/36 Fla:42

Kristina Engwall: De profesionellas syn på patienters... 
om kontakter med lokala myndigheter om hemmen var lämpliga för utskrivning av patienter.

\section{Det andra skedet: anhöriga blir viktiga}

Synen på de anhöriga kom radikalt att förändras under 1960-talet och början av 1970-talet. Tydligast syns förändringen hos de patienter som varit intagna sedan 1931 och som fortfarande vårdades på Västra Mark på 1970-talet. De professionella började då ta reda på patienternas släktförhållanden och söka kontakt med dem. Under 1970-talet hölls behandlingskonferenser om patienterna på Västra Mark. En av de punkter som då diskuterades var just kontakten med anhöriga. Journalanteckningar av följande slag dök upp: „Hon har aldrig under dessa 39 åren gjort någon resa till hemtrakten och inte ens heller haft besök av någon anhörig. Vi måste försöka att bättra på denna situation. ${ }^{46}$

Från sjukhusets sida sökte man upp anhöriga och försökte ordna besök. I ett fall ordnade man så att en patient fick träffa sin syster för första gången på 40 år. Av journalen framgår att systern var mycket nervös inför mötet. "Systern säger sig ej ha vågat resa för att hälsa på /namn/ under dennas vistelse på VMS.»Patienten på Västra Mark sade efter besöket »...'att detta var den lyckligaste dagen i hennes liv.' " 47

I flera fall uppmuntrade man kontakt mellan patienterna och deras barn. Av de patienter som hade flera barn var det inte ovanligt att patienten bara hade kontakt

46 37/31 Fla:14

47 90/31 Fla:49 med ett av barnen. ${ }^{48}$ I ett fall fick man sonen att besöka sin mor på Västra Mark. Modern hade dock både syn- och hörselnedsättningar och det blev svårt att förklara vem mannen som besökte patienten egentligen var. ${ }^{49}$ En annan patient som levt hela sitt liv på olika anstalter fick 35 år gammal besök av sin mor för första gången. Patienten var senare och hälsade på sin mor i hemmet. $^{50}$

Även om man inte lyckades att etablera kontakt med släktingar tilläts flera av patienterna göra besök i sina gamla hemtrakter. En patient besökte en familj i sin gamla hemort. Familjen i fråga hade lite kontakt med patientens bror och desssutom förstod de hennes gamla dialekt. ${ }^{51}$ Kontakten med hemorten kan även förklaras av att det nu blivit respektive landsting uppgift att ansvara för de utvecklingsstörda i länet. Från Västra Marks sida försökte man därför att ordna vårdplatser i patienternas hemlän. Utflyttningsprocessen försvårades av att det fanns för få vårdplatser i många landsting.

Förändringarna i relationen mellan de professionella och de anhöriga syns även $i$ det faktum att patienter kunde vistas på Västra Mark under kortare perioder för att avlasta familjen. Västra Mark blev ett komplement till hemmaboendet. Detta märks t.ex. i ett fall med en patient som sedan 1974 kom för kortare vistelser för att avlasta familjen. ${ }^{52}$ Synen på patienten har också förändrats. När meddelanden om utskriv-

48 Se t.ex. 111/31 Fla:6

49 128/31 Fla:3

50 24/56 Fla:88

51 19/36 Fla:35

52 3/81 Fla:123 
ning skickades ut, adresserades ett beslut direkt till patienten. ${ }^{53}$

De förändrade relationerna var dock inte helt enkla, varken för patienter eller anhöriga. Av ett exempel ovan framgår t.ex. systerns osäkerhet $i$ att möta sin syster från Västra Mark och hur hon inte vågat besöka henne tidigare. Den förändrade synen kunde innebära att de anhöriga kände press att hålla kontakt med patienterna (Färm, 1992). Det uppbrott som en anstaltsplacering orsakade gällde inte enbart patienten, utan det innebar även en stor förändring för de anhöriga. Att upprätta en relation efter kanske mer än trettio års tystnad var inte alltid helt enkelt.

\section{Varför förändring?}

Av journalmaterialet på Västra Mark framgår att det skett en radikal förändring i fråga om synen på anhöriga under 1960-talet. Kontakten med anhöriga betraktades som viktig för patienterna under 1960-talet. I princip kan två olika synsätt urskiljas under perioden 1931-1981 på Västra Mark, nämligen anhöriga som ointressanta och anhöriga som viktiga.

En annan indelning gör medicinalrådet Karl Grunewald (1995:87) då han blickar tillbaka på handikapphistoriens utveckling. Han menar att villkoren för föräldrarna till utvecklingsstörda under 1930- och 40-talen skulle kunna karaktäriseras som anonyma och isolerade, att de på 1950-och 60-talen blev intressanta och betydelsefulla i samhället och att föräldrarna under 1970-och 80talen blev experter. De olika synsätten behöver inte motsäga varandra. Skillnaderna

53 Se t.ex. 34/51 Fla:62 har snarare med Västra Marks speciella verksamhet att göra, där många patienter sedan tidig barndom hade varit anstaltsplacerade och därmed redan förlorat kontakten med anhöriga. Grunewald talar däremot om hur föräldrar till barn med utvecklingsstörning bemöttes, inte om föräldrarna till vuxna med utvecklingsstörning.

Vad beror då förändringarna på? Givetvis måste förändringarna sättas in $\mathrm{i}$ ett större samhälleligt sammanhang, där faktorer som förbättrad ekonomi, ökad kunskap och ett nytt sätt att se på förhållandet mellan individ och samhälle spelade in. I slutet av 1960-talet kom nya principer att styra verksamheten. Människor med utvecklingsstörning sågs som individer med rättigheter och utvecklingsmöjligheter istället för som tidigare vårdfall. På Västra Mark gick anpassningen till en modernare omsorg långsamt. Normaliseringsprincipen och den lilla gruppens princip introducerades på Västra Mark under 1970-talet. ${ }^{54}$ Antalet patienter blev färre. Som tidigare har nämnts kom även behandlingskonferenser och specifika målsättningar för de flesta patienter att utarbetas. ${ }^{55}$ Tidigare saknades individuella vårdprogram, istället handlade verksamheten om social fostran till en av samhället accepterad kvinnlighet.

Ytterligare orsaker till förändringarna kan sökas i synen på sinnesslöhet/utvecklingsstörning. Medan sinnesslö under 1930och 1940-talen var ett relativt godtyckligt

54 Landstingsarkivet i Örebro Årsberättelser B2:1Verksamhetsrapport 790208

55 Enligt lagen skulle samtliga patienter utredas, vilket dock inte skedde och sjukhuset kritiserades för.

Kristina Engwall: De profesionellas syn på patienters... 
begrepp utan klarlagda definitioner där delvis moraliska aspekter bedömdes (Runcis, 1998b), kom under 1950- och 1960-talen de medicinska orsakerna att upptäckas och nya begrepp som utvecklingshämmad och psykiskt utvecklingsstörd gjorde sig gällande. Stigmatiseringen minskade då medicinska förklaringar kunde fastslås och de mer vaga bedömningarna som byggde på omgivningens intryck av personen i fråga övergavs.

Överhuvudtaget präglades 1960-talet av diskussioner om tidigare eftersatta grupper, såsom zigenare, psykiskt sjuka, fångar etc. i samhället. Samtidigt som flera kategorier uppmärksammades, arbetade grupperna själva genom intresseföreningar för att göra sina stämmor hörda. Även människor med utvecklingsstörning blev intressanta och pressen hade flera skandalreportage om missförhållanden på vårdinstitutioner.

I de nya förhållanden som kom att gälla på bl.a. Västra Mark kom de anhöriga att få en ny roll. De anhöriga blev viktiga. På de professionellas inrådan söktes anhöriga till patienter upp. Även andra slags mänskliga kontakter togs. Röda korset hade t.ex. kontaktverksamhet med patienter på Västra Mark där rödakorsare både hälsade på patienter på Västra Mark och bjöd hem dem. Vissa patienter hade bättre kontakt med sin förmyndare än med sin släkt. ${ }^{56}$ Överhuvudtaget kom det att betraktas som viktigt med ett socialt kontaktnät som inte enbart bestod av personal och andra patienter på Västra Mark.

\section{Är det viktigt med anhöriga?}

På 1960-talet kom människors med utvecklingsstörning att respekteras i högre ut-

56 67/31 Fla:7 sträckning än tidigare och samtidigt blev de anhöriga betraktade som viktiga. Finns det något samband mellan dessa båda företeelser? Kan de sinnesslöas svaga ställning i samhället före 1960-talet delvis förklaras av deras försvagade kontakt med anhöriga?

Ytterligare en viktig bit i resonemanget är de professionellas starka ställning. I det utrymme som fanns för att fatta beslut om en sinnesslö människa (patienten) under den första perioden kan åtminstone tre aktörer urskiljas; patienten själv, de anhöriga och de professionella; såväl vårdpersonal som byråkrater (barnavårdsnämnd, fattigvård). Att patienten själv skulle fatta eller påverka beslut var en orimlig tanke under denna period. Medborgarskap hade i praktiken den som själv kunde försörja sig, men inte den som behövde ekonomisk hjälp. Var man dessutom betraktad som sinnesslö och intagen på anstalt fanns det ingenting som rättfärdigade egna beslut för den sinnesslöe. Inte heller de anhöriga hade mycket att säga till om i fråga om patienten. De anhörigas rätt att besluta om patienten hade i praktiken fråntagits dem av de professionella. Samarbetet mellan de professionella, läkarna och byråkraterna, vars verksamheter stöttade varandra var intensivt och lämnade inte något utrymme åt de anhöriga. De professionellas position utgick bl.a. från samhällets tilltro till deras kunskaper som i sin tur byggde på en stark övertygelse om vetenskapens förmåga att lösa samhälleliga problem.

I det rationella tänkandet kring de sinnesslöa kom de sinnesslöas egna önskningar och viljor att försvinna. De befann sig inte bara $\mathrm{i}$ en situation där de professionella hade tolkningsföreträde, deras handikapp 
(sinnesslöheten) innebar dessutom att de troligtvis hade problem att hävda sina åsikter. Det stöd som de anhöriga eventuellt kunde ha bidragit med undanrycktes också. Ansvaret för att hålla kontakten med anhöriga lades till stor del på patienterna, t.ex. genom brevskrivning. På så sätt drabbades de patienter hårdast som hade svårast att ta initiativ till brevskrivandet och som kan tänkas ha varit i störst behov av stöd. De patienter som själva var driftiga höll kontakten med sina anhöriga och begärde själva i skrivelser utskrivning. Detta hade de svagaste inte förmåga till.

\section{Spelade anhörigkontakten någon roll?}

Går det då att utläsa några skillnader mellan de patienter på Västra Mark som trots allt hade kontakt med sina anhöriga och de som inte hade det? Det är givetvis ett vanskligt företag att försöka visa att bra relationer till anhöriga påverkade patienternas situation till det bättre, medan frånvaron av anhöriga minskade patientens handlingsutrymme. Det finns dock vissa fall där jag menar att anhörigkontakten var av betydelse för patientens vård och framtid.

Ett exempel på detta är några patienter som inte blev steriliserade på Västra Mark. Patienterna som var på Västra Mark tillhörde den kategori som steriliseringslagstiftningen syftade på. Flera patienter steriliserades under tiden på Västra Mark eller var ändå infertila pga. ålder eller gynekologiska besvär. Patienter som stannade på Västra Mark behövde inte steriliseras, inte heller de patienter som flyttades till andra enkönade anstalter.

Vissa av patienterna protesterade mot steriliseringen, men det hjälpte bara i cirka en tredjedel av fallen. I andra fall var det föräldrar som protesterade mot steriliseringen. Annan forskning från barnavårdsnämder och rådgivningsbyråer visar dock att föräldrarnas protester inte hjälpte (Runcis, 1998a, Jönsson 1997). Många föräldrar har också $i$ egenskap av vårdnadshavare skrivit under sina barns steriliseringsansökan. På Västra Mark finns dock ett fåtal exempel där föräldrarna var mycket negativt inställda till sterilisering av deras barn och där barnen inte steriliserades. ${ }^{57}$ I ett fall tog modern istället på sig ansvaret att sköta p-pillermedicinering. ${ }^{58}$ Andra omständigheter utöver föräldrarnas protester bidrog givetvis också till att patienterna inte steriliserades.

Andra exempel som visar på betydelsen av anhöriga är de fall där patienterna före sin tid på Västra Mark bott tillsammans med sin mor och tack vare henne fungerat $i$ samhället ända fram till hennes död. När modern sedan dött har kvinnorna inte klarat sig på egen hand och omhändertagits..$^{59} \mathrm{En}$ patient började t.ex. "vagabondera" efter moderns död och omhändertogs. ${ }^{60}$ Mödrarna har under sin livstid stöttat döttrarna och sett till att de professionella inte haft anledning att lägga sig i döttrarnas liv. Då anhörigstödet försvann för dessa kvinnor fanns det inte längre någon som förde deras talan. Kvinnorna som blev i behov av vård då deras mödrar dog tillhörde de första patien-

57 Se t.ex. 3/51 Flb:28 och 10/66 Fla:115 samt RA Sinnessjuknämnden akter E1:48 (1941) diarie $937 / 41$

58 10/66 Fla:115

59 Se t.ex. 1/46 Fla:4 och 5/56 Flb:11

60 6/31 Fla:2

Kristina Engwall: De profesionellas syn på patienters... 
terna på Västra Mark. De är födda på slutet av 1800-talet eller i början av 1900-talet. Detta innebär också att människor omhändertogs vid allt yngre ålder under 1900-talet, vilket resulterade i att vissa patienter helt och hållet växte upp på olika anstalter.

Som tidigare nämndes placerades även straffriförklarade som ansågs vara imbecilla på Västra Mark. Tidigare framgick att dessa patienter i större omfattning var gifta eller hade varit gifta än de andra patienterna. Gruppen straffriförklarade patienter kunde enbart försöksutskrivas och utskrivas av sinnessjuknämnden, inte av överläkaren såsom var fallet för de andra patienterna. Vid en genomgång av de ärenden angående Västra Marks patienter som behandlats av sinnessjuknämnden märks att föräldrarna till denna grupp var aktiva. Både föräldrar och syskon har skrivit för att få sina straffriförklarade anhöriga utskrivna.

Undertecknad får härmed egenskap av fader till /namn/ som för närvarande på obestämd tid är intagen på Westra Marks sjukhus i Örebro, hos Kungl Medicinalstyrelsen, vördnadsfullt framställa en begäran att min dotter om möjligt genom Medicinalstyrelsens prövning kunde erhålla sin frihet.

Om denna innerliga önskan bifalles förklara jag mig fullt villig att påtaga mig ansvaret för hennes försörjning samt göra allt vad står $\mathrm{i}$ min makt för att hon hädanefter skall föra en hedersam levnadsvandel och bliva en god och laglydig medborgare ${ }^{61}$

Den här patienten var två år på Västra Mark innan hon försöksutskrevs. Helt utskriven blev hon två år senare enligt praxis. De straffriförklarade hade trots icke tidsbe-

61 RA sinnessjuknämnden akter E1:5 (1932) sammanträde den 22 dec $1932 \mathrm{nr} 338$ stämd vistelse kortare vårdtider än de andra patienterna. Även inom gruppen straffria har flera upplevt uppbrott i barndomen, trots detta tycks denna grupp haft större möjligheter att behålla ett kontaktnät med såväl anhöriga som bekanta.

\section{Vad kunde anhöriga bidraga med?}

Vad var det då anhöriga bidrog med eller inte fick möjlighet att bidraga med? För det första verkar det som om de anhöriga kunde utgöra en motvikt till de professionellas kunskapsmonopol om vad som var bäst för patienten. Detta kan jämföras med pedagogen Britta Högbergs reflektion om barnrehabiliteringen av idag (1996:107). Hon ifrågasätter vem som ska värna om det funktionshindrade barnets livsutrymme då föräldrar ses som partner till personalen i rehabiliteringen och därmed är en del av rehabiliteringen. Vem blir motvikt till de professionella? ${ }^{62}$

För det andra handlade det, enligt min mening, om att vara ett slags språkrör för patienten. Att försöka föra fram patientens vilja. Frågan kan ställas om inte den ökade kontakten med anhöriga på 1960-70-talen bidrog till ett ökat deltagande i samhället för de utvecklingsstörda och en ökad kunskap i samhället om utvecklingsstörda. Med andra ord, gavs de anhöriga under 1960-och 70-talen en möjlighet att fungera både som motvikt till de professionella och språkrör åt de utvecklingsstörda, vilket i sin tur gynnade de utvecklingsstördas ställning i samhället?

62 I detta sammanhang bör man komma ihåg att diskussionen om patientens eget medbestämmande ännu inte var aktuell. 


\section{Summary \\ Health care professionals - their view of contact between mental patients and relatives. Västra Mark 1931-1981}

The aim of this article is to see how the professional view of relationships between patients and their relatives has changed from the 1930s to the 1970s. This has been carried out by studying patients' records from a mental hospital, Västra Mark, where so-called antisocial and imbecile women were patients. The hospital opened in 1931 and was closed in 1981.

Contacts between the patients and their relatives involved the professionals (bureaucrats, doctors and nurses) as well as the families and the patients themselves. The extent of the contact between the patients and their families depended on how much the doctors and nurses valued this contact. The material from Västra Mark can be divided into two periods. During the first period from the 1930s to the beginning of the 1960s, the doctors did not deny their patients contact with their families, but visits and letters were not encouraged. Such contact as there was depended on the patients and their families taking the initiative. In the 1960s health care professionals started to regard relatives as an important part of the patients' lives, and they actually tried to locate relatives and helped the patients to visit them.

Is it important to involve relatives? Relatives may act as a counterweight to the authority of the health care professionals and act as a voice speaking on behalf of the patients. The new importance assigned to relatives was paralleled at the same time by a discussion of the rights of the disabled and improvements in their treatment and status. Could the improvements in the status of the disabled in society in the 1960s be, at least in part, attributed to the new view of the importance of relatives?

\section{Litteratur}

Bengtsson, Magdalena (1996) Det hotade barnet. Tre generationers spädbarns- och barnadödlighet i 1800-talets Linköping. Linköping: Tema. univ.

Färm, Kerstin (1992) Förändringen. Anhörigas synpunkter, tankar och villkor inför vårdhemsnedläggning. Rapport nr 15 Social- och omsorgsförvaltningen Örebro läns landsting.
Grunewald, Karl (1995) "Idéhistoriska strömningar på handikappområdet under min tid” i Eriksson, B-E och Törnqvist, R., red,: Likhet och särart. Handikapphistoria i Norden. Södertälje:Fingraf.

Gustavsson, Anders (1992) "Livet i 'integrasjonssamfunnet'-en analyse av naerhetens sosiale betydning", i Sandvin, J.T. red,: Mot normalt?

Kristina Engwall: De profesionellas syn på patienters... 
Omsorgsideologier i forandring.

Oslo:Kommuneforl.

Högberg, Britta (1996) Det handikappade barnet $i$

vuxenvärlden. En reflektion över möjligheten

att mötas. Stockholm:Univ.

Johannisson, Karin (1988) "Medicinhistoria idag", Lychnos. Årsbok för idé-och lärdomshistoria. Jönsson, Lars-Eric (1998) Det terapeutiska rum met. Rum och kropp i svensk sinnessjukvaird 1850-1970. Stockholm:Carlsson.

Jönson, Ulf (1997) Bråkiga, lösaktiga och nagelbi- tande barn: Ombarn och barnproblem vid en rådgivningsbyrå i Stockholm 1933-1950.

Linköping:Tema. univ.

Runcis, Maija (1998 a) Steriliseringar i folkhemmet. Stockholm:Ordfront.

Runcis, Maija (1998b) "Sinnesslöhet som samhällsproblem?” Historisk tidskrift, 4:547-567.

Steinholtz Ekecrantz, Lena (1995) Patienternas psykiatri. En studie av institutionella erfarenheter. Stockholm:Carlsson.

Söder, Mårten (1984) Anstalter för utvecklingsstörda, Stockholm:Stiftelsen ALA. 